\title{
Pengaruh Komposisi Dedak Dan Ukuran Baglog Terhadap Produksi Jamur Tiram Putih (Pleurotus ostreatus)
}

\section{The Effect of Bran Composition and Baglog Size on the Production of White Oyster Mushrooms (Pleurotus ostreatus)}

\author{
Sitti Nurlina ${ }^{1}$, Tutik Nugrahini ${ }^{2}$, Hamidah $^{2}$ \\ 1 Alumni Program Studi Agroteknologi, Fakultas Pertanian, Universitas Widya Gama Mahakam Jl. KH. Wahid \\ Hasyim, Sempaja, Samarinda, Kalimantan Timur, Indonesia \\ 2 Tenaga Pendidik Program Studi Agroteknologi, Fakultas Pertanian, Universitas Widya Gama Mahakam Jl. KH. \\ Wahid Hasyim, Sempaja, Samarinda, Kalimantan Timur, Indonesia
}

Email : sittinurlina@gmail.com, tutik.nugrahini@gmail.com, hamidah@uwgm.ac.id

Diterima : 4 April 2019 Disetujui : 17 Juni 2019

\begin{abstract}
The study was conducted to determine the effect of bran composition and baglog size on the production of white oyster mushrooms (Pleurotus ostreatus). The study was arranged in a Randomized Block Design (RBD) consisting of 2 factors with 5 replications. The first factor is the composition of bran consisting of four levels, namely: 10\%, 15\%,20\% and 25\%. The second factor is the size of baglog which consists of 4 levels, namely: $17 \mathrm{~cm}$, $18 \mathrm{~cm}, 19 \mathrm{~cm}$ and $20 \mathrm{~cm}$. The results showed that the composition of bran had a very significant effect on the age of the first harvest, average mushroom weight, average fresh weight per baglog and biological efficiency ratio. Baglog size has a significant effect on the age of the first harvest, average mushroom weight, average fresh weight per baglog and biological efficiency ratio. The best effect on the production of oyster mushrooms is produced by the composition of bran 20\% (d3) and baglog size of $19 \mathrm{~cm}$ (b3). The interaction of bran composition and baglog size significantly affected the age of the first harvest and had a very significant effect on the average weight of mushrooms, but did not significantly affect the fresh weight of mushrooms per baglog and the ratio of biological efficiency. The best interaction with the production of white oyster mushrooms is a combination of 20\% bran composition and $19 \mathrm{~cm}$ baglog size.
\end{abstract}

Keywords: White oyster mushroom, Pleurotus ostreatus, bran, baglog

\section{PENDAHULUAN}

Jamur tiram (Pleurotus ostreatus) termasuk jenis sayuran yang sudah dikenal masyarakat sebagai bahan pangan. Seiring dengan populasi jamur sebagai bahan makanan yang enak dan bergizi karena di dalamnya terkandung 9 asam amino esensial dengan kadar protein $19-35 \%$ (Rochman, 2015), permintaan jamur tiram di masyarakat terus meningkat. Masyarakat tertentu sudah mulai memilih jenis makanan yang bebas dari pencemaran bahan pangan seperti residu pupuk dan pestisida serta tidak mengandung kolesterol (Sumarmi, 2006).

Gizi yang terkandung dalam badan buah jamur tiram meliputi karbohidrat, protein, lemak, mineral dan vitamin. Jenis karbohidrat yang terkandung dalam badan buah jamur kaya akan serat dan lebih aman dibandingkan dengan gula, sehingga bermanfaat bagi kesehatan dan meningkatkan stamina tubuh. Lemak yang berasal dari jamur mengandung jenis lemak esensial seperti asam linoleat, lenolenat, dan arakidonat yang dapat mencegah penyempitan pembuluh darah akibat penumpukan kolesterol (Sugianto, 2017).

Badan buah jamur tiram mengandung vitamin atau bakal vitamin (precursor) yang dapat dirubah dalam tubuh menjadi vitamin aktif. Vitamin tersebut antara lain Tiamin, Riboflavin dan Niasin. Jamur tiram juga mengandung unsur mineral makro seperti natrium, kalsium, fosfor, klor, magnesium dan belerang, dan unsur mineral mikro seperti besi, iodium, mangan, tembaga, zink, kobalt, dan fluor (Sugianto, 2017). Pasar jamur tiram sangat potensial, selain untuk kebutuhan konsumsi dalam negeri, produk ini juga dapat menembus pasar ekspor.

Permintaan jamur setiap tahun meningkat sekitar 20-25\%. Sebagian besar produksi jamur dipasarkan dalam bentuk segar, dengan menciptakan berbagai jenis makanan olahan jamur, tentunya akan membuka peluang baru dan membuat komoditas jamur makin prospektif. Dengan demikian prospek usaha jamur perlu ditumbuh kembangkan dengan cara membudidayakan jamur tiram secara komersial (Maulana, 2012).

Keberhasilan budidaya jamur tiram putih ditentukan oleh semakin tingginya produksi jamur dari tiap media tanam. Untuk meningkatkan produksi jamur tiram maka dalam campuran media tanam berupa serbuk gergaji sebagai bahan utama, perlu bahan tambahan lain yang kaya nutrisi, yaitu berupa bekatul (dedak) 
dan tepung jagung. Kegunaan penambahan bekatul dan tepung jagung merupakan sumber karbohidrat, lemak, protein, vitamin dan mineral (Widyastuti dan Tjokrokusumo, 2008).

Dedak ditambahkan untuk meningkatkan nutrisi media tanam sebagai sumber karbohidrat, sumber karbon, nitrogen, vitamin dan abu (mineral) (Sugianto, 2017). Komposisi pemberian bahan tambahan berupa dedak adalah antara 10-15\% (Suriawiria 2002). Menurut Achmad dkk (2011) untuk budidaya jamur yang menggunakan bahan bantu berupa bekatul (dedak), pemakaiannya antara $15-20 \%$ dari jumlah keseluruhan bahan. Jika lebih, media jamur akan mudah terkontaminasi. Karena tingginya kadar nutrisi dalam media tumbuh jamur, memungkinkan jamur lain untuk hidup dan berkompetisi dengan miselium jamur tiram

\section{BAHAN DAN METODE}

Penelitian dilaksanakan selama 6 bulan terhitung bulan Agustus 2016 - Februari 2017. Penelitian dilaksanakan di Usaha Borneo Mitra Jamur jl. Gunung Lingai RT.4 Samarinda. Alat yang digunakan adalah kumbung, rak, ayakan serbuk kayu, timbangan, neraca analitik, sekop, sterilisator, spatula, bunsen/ pembakar spiritus dan termohygrometer. Bahan yang digunakan antara lain bibit jamur tiram putih, serbuk kayu sengon, dedak, biji jagung, kapur putih. Beberapa jamur kontaminan yang sering menyerang dan berkompetisi dengan Pleurotus ostreatus yaitu Penicillium sp, Aspergillus sp, dan Trichoderma sp (Suriawiria, 2000).

Faktor lain yang juga dapat meningkatkan hasil produksi jamur adalah ukuran baglog. Ukuran baglog menentukan nutrisi yang dapat diserap oleh jamur (Istianti, 2012). Umumnya petani menggunakan baglog dengan ukuran lebar yang variatif yaitu $17 \mathrm{~cm}, 18 \mathrm{~cm}, 19 \mathrm{~cm}$ dan $20 \mathrm{~cm}$. Pemberian komposisi dedak dan ukuran lebar baglog yang tepat dalam meningkatkan produksi jamur tiram putih dapat diketahui dengan melakukan penelitian tentang "Pengaruh komposisi dedak dan ukuran baglog terhadap produksi jamur tiram putih (Pleurotus ostreatus)".

$\left(\mathrm{CaCO}_{3}\right)$ sebagai pengatur $\mathrm{pH}$, air, cincin plastik, plastik Poly Propylene ketebalan $0,5 \mathrm{~mm}$, lebar $17 \mathrm{~cm}, 18 \mathrm{~cm}, 19 \mathrm{~cm}$ dan $20 \mathrm{~cm}$ dan panjang 35 $\mathrm{cm}$, alkohol $70 \%$, spiritus, dan baglog dengan berat $1 \mathrm{~kg}$. Penelitian ini menggunakan Rancangan Acak Kelompok (RAK) Faktorial dengan 2 faktor dan diulang sebanyak 5 kali. Faktor pertama adalah komposisi dedak (D) yang terdiri dari 4 taraf yaitu : $\mathrm{d} 1: 10 \%, \mathrm{~d} 2$ : $15 \%, \mathrm{~d} 3: 20 \%, \mathrm{~d} 4: 25 \%$. Faktor kedua adalah ukuran lebar baglog (B) terdiri dari 4 taraf yaitu : b1 : $17 \mathrm{~cm}, \mathrm{~b} 2: 18 \mathrm{~cm}, \mathrm{~b} 3: 19 \mathrm{~cm}, \mathrm{~b} 4: 20 \mathrm{~cm}$.

\section{HASIL DAN PEMBAHASAN}

\section{Pengaruh Komposisi Dedak Terhadap Produksi Jamur Tiram Putih}

Tabel 1. Pengaruh Komposisi Dedak Terhadap Produksi Jamur Tiram Putih

\begin{tabular}{ccccc}
\hline Perlakuan & $\begin{array}{c}\text { Umur Panen Pertama } \\
(\mathrm{hst})\end{array}$ & $\begin{array}{c}\text { Rata-rata Bobot } \\
\text { Jamur }(\mathrm{g})\end{array}$ & $\begin{array}{c}\text { Bobot Segar Jamur } \\
\text { Per Baglog }(\mathrm{g})\end{array}$ & $\begin{array}{c}\text { Rasio Efisiensi } \\
\text { Biologis (\%) }\end{array}$ \\
\hline d1 & $59,05^{\mathrm{c}}$ & $69,15^{\mathrm{a}}$ & $269,35^{\mathrm{a}}$ & $26,93^{\mathrm{a}}$ \\
d2 & $54,15^{\mathrm{b}}$ & $77,16^{\mathrm{a}}$ & $330,15^{\mathrm{b}}$ & $33,01^{\mathrm{b}}$ \\
d3 & $48,65^{\mathrm{a}}$ & $99,00^{\mathrm{b}}$ & $400,70^{\mathrm{c}}$ & $40,07^{\mathrm{c}}$ \\
d4 & $52,75^{\mathrm{ab}}$ & $78,41^{\mathrm{a}}$ & $316,05^{\mathrm{b}}$ & $31,60^{\mathrm{b}}$ \\
\hline
\end{tabular}

Keterangan : Angka-angka dengan salah satu superscript yang sama pada kolom yang sama menunjukkan hasil tidak berbeda nyata berdasarkan uji DMRT dengan taraf 5\%

Hasil penelitian menunjukkan bahwa komposisi dedak berpengaruh sangat nyata terhadap umur panen pertama. Pemberian komposisi dedak $20 \%$ (d3) memberikan hasil terbaik dengan umur panen pertama tercepat

kandungan karbohidrat dan protein yang lebih tinggi pula pada perlakuan $\mathrm{d} 3$ dan $\mathrm{d} 4$. Komposisi dedak yang tepat menunjang metabolisme pertumbuhan miselia sehingga dapat mempercepat masa panen. Nutrien merupakan stimulus untuk pertumbuhan badan buah. Pembentukan badan buah secara tidak langsung dipengaruhi oleh pertumbuhan yaitu 48,65 hari yang tidak berbeda nyata dengan perlakuan d4 (komposisi dedak 25\%). Hal ini diduga komposisi dedak mempengaruhi kecepatan tumbuh miselium. Dengan komposisi dedak yang lebih tinggi, memberikan miselium, karena pertumbuhan miselium merupakan tahap awal pembentukan badan buah. Sebagai saprofit (organisme yang hidup dengan memperoleh bahan organik dari organisme yang telah mati), jamur tiram menggunakan sumber karbon yang berasal dari bahan organik untuk diuraikan menjadi senyawa 
karbon sederhana kemudian diserap masuk ke dalam miselia jamur (Suharnowo dkk, 2012).

Komposisi dedak berpengaruh sangat nyata pada rata-rata bobot jamur. Hasil terbaik ditunjukkan oleh perlakuan komposisi dedak $20 \%$ (d3) dengan rata-rata 99,00 g. Hal ini diduga karena dedak mengandung karbohidrat struktural $10 \%$, protein total $7,5 \%$, lemak $2,25 \%$ dan berbagai mineral sampai 7,5\% (Sutarman, 2012), selain itu dedak kaya akan vitamin terutama vitamin B kompleks, merupakan bagian yang berperan dalam pertumbuhan dan perkembangan miselia jamur serta berfungsi sebagai pemicu pertumbuhan badan buah (Suriawiria, 2002).

Dedak atau bekatul diperlukan baik dalam pembuatan bibit maupun media tanam jamur sebagai tambahan sumber karbohidrat atau karbon dan mineral. Karbon dibutuhkan oleh miselium jamur sebagai sumber energi untuk pertumbuhannya. Untuk budidaya jamur yang menggunakan bahan bantu berupa bekatul (dedak), pemakaiannya antara $15-20 \%$ dari jumlah keseluruhan bahan. Jika lebih, media jamur akan mudah terkontaminasi (Achmad dkk, 2011). Terjadinya kontaminasi disebabkan tingginya kadar nutrisi dalam media tanam yang dapat menyebabkan jamur lain hidup dan berkompetisi dengan jamur tiram. Pada perlakuan $\mathrm{d} 1$ dan $\mathrm{d} 2$ nutrisi dari komposisi dedak yang dibutuhkan dalam pembentukan badan buah jamur lebih sedikit dibandingkan pada perlakuan d3. Sementara pada perlakuan d4 yang dengan komposisi dedak yang lebih tinggi terjadi kontaminasi pada saat masa inkubasi sehingga menghambat pertumbuhan miselia. Komposisi dedak berpengaruh sangat nyata pada bobot segar jamur per baglog. Perlakuan terbaik adalah pada perlakuan d3 (komposisi dedak 20\%) dengan bobot segar per baglog 400,7 g. Hal ini diduga karena komposisi dedak sebesar $20 \%$ mampu memberikan suplai nutrisi yang lebih baik selama masa pertumbuhan jamur dibandingkan dengan perlakuan lainnya. Selain itu komposisi dedak $20 \%$ memiliki peluang terkontaminasi lebih kecil dibandingkan dengan komposisi dedak yang lebih tinggi. Bobot segar jamur per baglog dari perlakuan komposisi dedak $20 \%$ memberikan hasil yang lebih baik dibandingkan data hasil produksi jamur tiram di Kelurahan Lempake Kota Samarinda yang hanya mencapai 269 g (Fermansyah, 2012). Komposisi dedak berpengaruh sangat nyata pada Rasio Efisiensi Biologis. Perlakuan terbaik yaitu pada perlakuan d3 (komposisi dedak 20\%) dengan REB 40,07 $\%$. Konversi bahan-bahan lignoselulosa menjadi badan buah jamur yang dapat dimakan merupakan aspek yang sangat penting dalam penanaman jamur. Hal tersebut dapat ditunjukkan dengan menggunakan nilai REB (Rasio Efisiensi Biologis). Nilai REB didapatkan dari hasil perbandingan antara berat segar badan buah dengan berat media tumbuh jamur (Maulana, 2012). Dalam pertumbuhan dan perkembangannya jamur tiram putih memperoleh makanan dengan cara mengeluarkan enzim-enzim yang dapat mendegradasi komponen selulosa, hemiselulosa, dan lignin menjadi gula sederhana. Gula sederhana ini digunakan untuk pembentukan badan buah. Semakin banyak jumlah rumpun dan jumlah badan buah jamur tiram putih maka semakin banyak pula enzim yang dihasilkan untuk mendegradasi substart menjadi gula sederhana, mengakibatkan meningkatnya gula sederhana yang dapat dimanfaatkan untuk pertumbuhan badan buah (Simatupang dkk, 2013).

\section{Pengaruh Ukuran Baglog Terhadap Produksi Jamur Tiram Putih}

Hasil penelitian menunjukkan bahwa adanya pengaruh sangat nyata dari ukuran baglog terhadap umur panen pertama. Umur panen pertama terbaik adalah hasil perlakuan b3 (ukuran baglog $19 \mathrm{~cm}$ ) yaitu 48,1 hari yang tidak berbeda nyata dengan perlakuan b4 (ukuran baglog $20 \mathrm{~cm}$ ). Hal ini diduga karena ukuran baglog $19 \mathrm{~cm}$ dan $20 \mathrm{~cm}$ memungkinkan penyerapan oksigen yang optimal saat miselia telah memenuhi baglog. Sehingga pembentukan primordia lebih cepat dan masa panen jamur lebih singkat. Menurut Gunawan (1993), perkembangan miselium jamur tiram putih menjadi primordium membutuhkan aerasi dan paling cepat terjadi pada perlakuan teknik aerasi dengan melepaskan seluruh kantong plastik pembungkus media produksi. Menurut Achmad dkk (2011), setelah media tanam (baglog) dipenuhi oleh miselia jamur tiram, pembentukan badan buah jamur tiram dimulai, perlakuan yang diberikan diawali dengan pemberian tekanan berupa perbedaan suhu, kelembaban serta pemberian oksigen. 
Tabel 2. Pengaruh Ukuran Baglog Terhadap Produksi Jamur Tiram Putih

\begin{tabular}{ccccc}
\hline $\begin{array}{c}\text { Perlakua } \\
\mathrm{n}\end{array}$ & $\begin{array}{c}\text { Umur Panen Pertama } \\
(\mathrm{hst})\end{array}$ & $\begin{array}{c}\text { Rata-rata Bobot } \\
\text { Jamur }(\mathrm{g})\end{array}$ & $\begin{array}{c}\text { Bobot Segar Jamur Per } \\
\text { Baglog }(\mathrm{g})\end{array}$ & $\begin{array}{c}\text { Rasio Efisiensi } \\
\text { Biologis }(\%)\end{array}$ \\
\hline b1 & $58,95^{\mathrm{b}}$ & $67,45^{\mathrm{a}}$ & $303,25^{\mathrm{a}}$ & $30,32^{\mathrm{a}}$ \\
b2 & $56,15^{\mathrm{b}}$ & $69,45^{\mathrm{a}}$ & $325,65^{\mathrm{ab}}$ & $32,56^{\mathrm{ab}}$ \\
b3 & $48,10^{\mathrm{a}}$ & $101,09^{\mathrm{c}}$ & $349,1^{\mathrm{b}}$ & $34,91^{\mathrm{b}}$ \\
b4 & $51,40^{\mathrm{a}}$ & $85,73^{\mathrm{b}}$ & $338,25^{\mathrm{b}}$ & $33,82^{\mathrm{b}}$ \\
\hline
\end{tabular}

Keterangan: Angka-angka dengan salah satu superscript yang sama pada kolom yang sama menunjukkan hasil tidak berbeda nyata berdasarkan uji DMRT dengan taraf 5\%

Ukuran baglog memberikan pengaruh sangat nyata terhadap rata-rata bobot jamur. Hasil terbaik ditunjukkan oleh perlakuan b3 (ukuran baglog $19 \mathrm{~cm}$ ) dengan hasil 101,3 g. Hal ini diduga disebabkan oleh tercukupinya jumlah oksigen dan karbondioksida yang dibutuhkan oleh miselia dalam membentuk primordia dan badan buah jamur. Dengan ukuran baglog yang tepat, maka jumlah oksigen dan karbondioksida yang berinteraksi dengan media tanam dapat dioptimalkan. Sedangkan pada perlakuan b4 (ukuran baglog $20 \mathrm{~cm}$ ) diduga rata-rata bobot segar jamur lebih kecil dikarenakan lebih besarnya area penguapan baglog sehingga media tanam lebih mudah kering dan tidak dapat lagi menghasilkan primordia dan badan buah jamur.

Ukuran baglog juga memberikan pengaruh sangat nyata terhadap bobot segar jamur per baglog. Perlakuan terbaik yaitu pada perlakuan b3 (ukuran baglog $19 \mathrm{~cm}$ ) dengan bobot segar per baglog $349,1 \mathrm{~g}$ yang tidak berbeda nyata dengan perlakuan b2 dan b4. Hal ini diduga disebabkan oleh optimalnya penyerapan oksigen dan kejutan fisik pada baglog berukuran $19 \mathrm{~cm}$. Menurut Maulana (2012), agar bakal badan buah dapat terbentuk, biasanya dibutuhkan kejutan fisik seperti perubahan suhu, cahaya, tingkat $\mathrm{CO}_{2}$, kelembaban relatif udara dan aerasi.

Ukuran baglog memberikan pengaruh sangat nyata terhadap terhadap REB. Dan berdasarkan uji lanjutan dengan metode DMRT 5\% diperoleh perlakuan terbaik yaitu pada perlakuan b3 (ukuran baglog $19 \mathrm{~cm}$ ) dengan bobot segar per baglog $34,91 \mathrm{~g}$ yang tidak berbeda nyata dengan perlakuan b2 dan b4. Hal ini diduga disebabkan oleh optimalnya penyerapan oksigen dan kejutan fisik pada baglog berukuran $19 \mathrm{~cm}$ menyebabkan tingginya pertumbuhan badan buah, sehingga mempengaruhi nilai REB. Kondisi lingkungan secara tidak langsung dapat mempengaruhi nilai Rasio Efisiensi Biologi. Meningkatkan pertumbuhan badan buah akan meningkatkan nilai REB. Dua komponen penting dalam udara yang berpengaruh pada pertumbuhan jamur yaitu oksigen dan karbondioksida. Oksigen merupakan unsur penting dalam respirasi sel. Sumber energi di dalam sel dioksidasi menjadi karbondioksida dan air sehingga energi menjadi tersedia. Karbondioksida dapat berakumulasi sebagai hasil respirasi oleh jamur itu sendiri atau respirasi oleh organisme lain (Afief, 2015).

\section{Pengaruh Interaksi Komposisi Dedak Dan Ukuran Baglog Terhadap Produksi Jamur Tiram Putih}

Hasil penelitian menunjukkan bahwa adanya pengaruh nyata dari interaksi komposisi dedak dan ukuran baglog terhadap umur panen pertama jamur tiram putih. Dan berdasarkan uji lanjutan dengan metode DMRT 5\% diperoleh perlakuan terbaik yaitu pada perlakuan d3b3 (komposisi dedak 20\% dan ukuran baglog $19 \mathrm{~cm}$ ) dengan waktu rata-rata 42 hari. Hal ini diduga disebabkan oleh terpenuhinya nutrisi yang dibutuhkan oleh pertumbuhan miselium serta optimalnya kondisi lingkungan yang berinteraksi dengan media tanam (baglog) sehingga mendukung penyebaran miselia pada baglog serta mempercepat munculnya primordium yang akan tumbuh menjadi badan buah. Menurut Maulana (2012), produktivitas jamur tiram tergantung pada kandungan nutrisi media tanam, kualitas bibit serta lingkungan selama pemeliharaan. Panen jamur tiram dapat dilakukan biasanya setelah 45-67 hari setelah inokulasi.

Hal ini sesuai dengan pendapat Wijoyo (2011) yang mengemukakan bahwa bekatul atau dedak merupakan sumber karbohidrat, lemak dan protein. Dedak kaya akan vitamin, terutama vitamin B kompleks, dan merupakan bagian yang berperan dalam pertumbuhan dan perkembangan miselia jamur serta berfungsi sebagai pemicu pertumbuhan buah. Selain kandungan nutrisi yang terkandung dalam media tanam, menurut Maulana (2012), lingkungan memegang peranan penting untuk mendapatkan pertumbuhan badan buah yang optimal, apabila kondisi lingkungan pertumbuhan tidak terpenuhi, maka akan menghambat pertumbuhan jamur tiram, baik penyebaran miselia jamur pada fase inkubasi maupun pada fase pembentukan badan buah (primordium). Cepat dan lamanya waktu panen berkaitan dengan pertumbuhan primordium pada media. 
Pertumbuhan primordium berkaitan dengan ketersediaan Oksigen, Winarni dan Rahayu (2002). Dalam proses pertumbuhan primordium, ukuran baglog akan menentukan tingkat penyerapan oksigen dan karbondioksida serta kemampuan miselia berinteraksi dengan suhu udara dan kelembaban dari lingkungan pertumbuhan jamur.

Tabel 3. Pengaruh Interaksi Komposisi Dedak Dan Ukuran Baglog Terhadap Produksi Jamur Tiram Putih

\begin{tabular}{|c|c|c|c|c|}
\hline Perlakuan & $\begin{array}{c}\text { Umur Panen Pertama } \\
(\mathrm{hst})\end{array}$ & $\begin{array}{l}\text { Rata-rata Bobot } \\
\text { Jamur }(\mathrm{g})\end{array}$ & $\begin{array}{l}\text { Bobot Segar Jamur } \\
\text { Per Baglog (g) }\end{array}$ & $\begin{array}{c}\text { Rasio Efisiensi } \\
\text { Biologis }(\%)\end{array}$ \\
\hline d1b1 & $68^{\mathrm{g}}$ & $55,21^{\mathrm{a}}$ & $252,4^{\mathrm{a}}$ & $25,24^{\mathrm{a}}$ \\
\hline $\mathrm{d} 1 \mathrm{~b} 2$ & $62,8^{\mathrm{f}}$ & $56,99^{a}$ & $271,2^{\mathrm{ab}}$ & $27,12^{\mathrm{ab}}$ \\
\hline d1b3 & $51^{\mathrm{bcd}}$ & $83,37^{\mathrm{def}}$ & $266^{\mathrm{ab}}$ & $26,6^{\mathrm{ab}}$ \\
\hline $\mathrm{d} 1 \mathrm{~b} 4$ & $54,4^{\text {cde }}$ & $81,03^{\text {de }}$ & $287,8^{\text {bcd }}$ & $28,78^{\text {bcd }}$ \\
\hline $\mathrm{d} 2 \mathrm{~b} 1$ & $58,4^{\mathrm{e}}$ & $67,13^{\mathrm{b}}$ & $280,6^{\mathrm{abc}}$ & $28,06^{\mathrm{abc}}$ \\
\hline $\mathrm{d} 2 \mathrm{~b} 2$ & $57,4^{\mathrm{e}}$ & $68,86^{\mathrm{bc}}$ & $329,4^{\mathrm{e}}$ & $32,94^{\mathrm{e}}$ \\
\hline $\mathrm{d} 2 \mathrm{~b} 3$ & $49,2^{\mathrm{b}}$ & $92,65^{\mathrm{fg}}$ & $370,6^{\mathrm{fg}}$ & $37,06^{\mathrm{fg}}$ \\
\hline $\mathrm{d} 2 \mathrm{~b} 4$ & $51,6^{\text {bcd }}$ & $85^{\text {def }}$ & $340^{\mathrm{ef}}$ & $34^{\mathrm{ef}}$ \\
\hline $\mathrm{d} 3 \mathrm{~b} 1$ & $54,2^{\text {cde }}$ & $77,96^{\mathrm{cd}}$ & $389,8^{\mathrm{gh}}$ & $38,98^{\mathrm{gh}}$ \\
\hline $\mathrm{d} 3 \mathrm{~b} 2$ & $50,2^{\mathrm{bc}}$ & $90,34^{\mathrm{efg}}$ & $394^{\text {gh }}$ & $39,4^{\text {gh }}$ \\
\hline $\mathrm{d} 3 \mathrm{~b} 3$ & $42^{\mathrm{a}}$ & $131,65^{\mathrm{h}}$ & $417,2^{\mathrm{h}}$ & $41,72^{\mathrm{h}}$ \\
\hline $\mathrm{d} 3 \mathrm{~b} 4$ & $48,2^{\mathrm{b}}$ & $96,03^{\mathrm{g}}$ & $401,8^{\text {gh }}$ & $40,18^{\text {gh }}$ \\
\hline $\mathrm{d} 4 \mathrm{~b} 1$ & $55,2^{\mathrm{de}}$ & $69,50^{\mathrm{bc}}$ & $290,2^{\mathrm{bcd}}$ & $29,02^{\mathrm{bcd}}$ \\
\hline $\mathrm{d} 4 \mathrm{~b} 2$ & $54,2^{\text {cde }}$ & $61,6^{\mathrm{ab}}$ & $308^{\text {cde }}$ & $30,8^{\text {cde }}$ \\
\hline $\mathrm{d} 4 \mathrm{~b} 3$ & $50,2^{\mathrm{bc}}$ & $96,7^{\mathrm{g}}$ & $342,6^{\text {ef }}$ & $34,26^{\mathrm{ef}}$ \\
\hline $\mathrm{d} 4 \mathrm{~b} 4$ & $51,4^{\text {bcd }}$ & $80,85^{\mathrm{de}}$ & $323,4^{\text {de }}$ & $32,34^{\text {de }}$ \\
\hline
\end{tabular}

Keterangan: Angka-angka dengan salah satu superscript yang sama pada kolom yang sama menunjukkan hasil tidak berbeda nyata berdasarkan uji DMRT dengan taraf 5\%

Hasil penelitian menunjukkan bahwa adanya pengaruh sangat nyata dari interaksi komposisi dedak dan ukuran baglog terhadap rata-rata bobot jamur. Hasil terbaik adalah pada perlakuan d3b3 (komposisi dedak 20\% dan ukuran baglog $19 \mathrm{~cm}$ ) dengan bobot segar rata-rata $131,65 \mathrm{~g}$. Dedak mengandung 84,36 \% karbohidrat, 8,77 \% protein, $1,69 \%$ serat, $1,09 \%$ lemak dan abu $1,60 \%$ (Rochman, 2015). Karbohidrat berfungsi sebagai sumber karbon yang merupakan unsur penting yang dibutuhkan jamur sebagai sumber energi dalam menjalankan metabolismenya. Penambahan karbohidrat yang lebih banyak dapat mempercepat munculnya badan buah dan menambah berat basah badan buah jamur (Suharnowo, 2012).

Menurut Winarni dan Rahayu (2002), tingginya hasil jamur tiram karena bekatul atau dedak yang diberikan pada media dapat menambah kandungan nutrisi, karena dedak mengandung nitrogen (untuk sistesis protein) dan thiamin (vitamin b1) yang berfungsi untuk merangsang pertumbuhan miselium dan pertumbuhan badan buah jamur tiram. Selain kandungan nutrisi dalam media tanam, menurut Maulana (2012), pertumbuhan badan buah jamur tiram akan terjadi jika ada stimulasi yaitu cukup tersedia oksigen, cahaya dan kondisi lingkungan lembab sampai sangat lembab $>80 \%$ dengan suhu $24-28^{\circ} \mathrm{C}$. Dalam hal ini ukuran baglog menentukan tingkat penyerapan oksigen serta kondisi lingkungan tumbuh jamur tiram.

Hasil penelitian menunjukkan bahwa interaksi komposisi dedak dengan ukuran baglog tidak berpengaruh nyata pada rata-rata bobot segar jamur per baglog. Hasil bobot segar jamur per baglog tertinggi adalah 417,2 g dari perlakuan d3b3 dan hasil terendah adalah 252,4 dari perlakuan d1b1. Hal ini diduga karena interaksi komposisi dedak dengan ukuran baglog tidak mempengaruhi jumlah masa panen jamur tiram putih. Dari hasil penelitian diperoleh masa panen berkisar antara 3 sampai 5 kali. Pada umumnya baglog menghasilkan bobot jamur segar yang tinggi hanya pada masa panen pertama, kemudian menurun pada panen berikutnya, sehingga ratarata bobot segar jamur per baglog (akumulasi hasil panen) menunjukkan tidak berbeda nyata antar seluruh perlakuan.

Hasil penelitian menunjukkan bahwa interaksi komposisi dedak dengan ukuran baglog tidak berpengaruh nyata nilai Rasio Efisiensi Biologis. Hasil Rasio Efisiensi Biologis tertinggi adalah $41,72 \%$ dari perlakuan d3b3 dan hasil terendah adalah $25,24 \%$ dari perlakuan d1b1. Hal ini dikarenakan interaksi komposisi dedak dengan ukuran baglog tidak berpengaruh nyata pada ratarata bobot segar jamur per baglog, sehingga juga tidak memberikan pengaruh pada nilai Rasio 
Efisiensi Biologis. Meskipun tidak memberikan pengaruh terhadap Rasio Efisiensi Biologis, perlakuan interaksi komposisi dedak dan ukuran baglog dapat mencapai nilai Rasio Efisiensi Biologis sebesar 41,72\%. Menurut Suriawiria (2002), penggunaan suatu media dapat dikatakan layak jika nilai REB lebih besar dari $40 \%$, dan semakin tinggi nilai REB, semakin baik budidaya jamur tersebut.

\section{KESIMPULAN}

1. Perlakuan komposisi dedak berpengaruh sangat nyata terhadap produksi jamur tiram putih. Perlakuan terbaik adalah komposisi dedak 20\% (d3) menghasilkan umur panen pertama 48,65 hst, rata-rata bobot jamur sebesar 99,00 g, bobot segar jamur per baglog sebesar 400,7 g dan Rasio Efisiensi Biologis $40,07 \%$.

\section{DAFTAR PUSTAKA}

Achmad., Mugiono., Arlianti, Tias., Azmi, Chotimatul. 2011. Panduan Lengkap Jamur. Penebar Swadaya, Jakarta.

Afief, M Fadhil., Lahay, R Rosanty., Siagian, Balonggu. 2015. Respon Pertumbuhan dan Produksi Jamur Tiram (Pleurotus ostreatus) Terhadap Berbagai Media Serbuk Kayu dan Pemberian Pupuk NPK. Jurnal Online Agroteknologi. Vol.3. No.4. September 2015.(520) : 1381-1390.

Encyclopedia of Life (EOL). 2017. Pleurotus ostreatus (Jacq.) P. Kumm. 1871. http://eol.org, [online]. diakses tanggal 13 November 2017.

Fauzi, Mahdi., Nisa, T Chairun., Syukri. 2013. Pengaruh Tiga Media Tanam Serbuk Kayu dan Pemberian Pupuk pada Produksi Jamur Tiram Putih (Pleurotus ostreatus (var). Florida). Jurnal Online Agroteknologi. Vol.1.No.2.Maret 2013.

Fermansyah, Emnat. 2012. Analisis Biaya Produksi dan Pendapatan Usaha Jamur Tiram Putih (Pleurotus ostreatus) (Studi Kasus Pada Petani Jamur Tiram Putih di Kelurahan Lempake Kecamatan Samarinda Utara). Jurnal Ekonomi Pertanian dan Pembangunan.Vol.9 No.1.2012: 9-12.
2. Perlakuan ukuran baglog berpengaruh sangat nyata terhadap produksi jamur tiram putih. Perlakuan terbaik adalah ukuran baglog $19 \mathrm{~cm}$ (b3) menghasilkan umur panen pertama 48,1 hst, rata-rata bobot jamur sebesar 101,09 g, bobot segar jamur per baglog sebesar 349,1 g dan Rasio Efisiensi Biologis 34,91\%

3. Interaksi komposisi dedak dan ukuran baglog berpengaruh nyata terhadap umur panen pertama jamur tiram putih, dan berpengaruh sangat nyata terhadap rata-rata bobot jamur tiram putih. Perlakuan terbaik adalah komposisi dedak 20\% dan ukuran baglog 19 $\mathrm{cm}$ (d3b3) yang menghasilkan umur panen pertama tercepat yaitu 42 hst dan rata-rata bobot segar saat panen sebesar 131,65 g.

Gunawan, A. Widya. 1993. Tiga Metode Aerasi Pada Budidaya Jamur Tiram Putih. Jurnal Mikrobiologi Indonesia. Vol.2 No.2 1993.

Islami, Andini., Purnomo, Adi Setyo., Sukesi. 2013. Pengaruh Komposisi Ampas Tebu dan Kayu Sengon Sebagai Media Pertumbuhan Terhadap Nutrisi Jamur Tiram (Pleurotus ostreatus). Jurnal Sains dan Semi Pomits. Vol.2 No.1.(2013) 2337-3520 (2301-928X Print).

Istianti, Dwik. 2012. Respon Pertumbuhan Dan Produksi Jamur Tiram Putih (Pleurotus ostreatus) Terhadap Kombinasi Jenis Pupuk (SP36, Biosugih Dan Pupuk Kandang Ayam) Dan Berbagai Ukuran Baglog. Skripsi (tidak dipublikasikan). Universitas Widya Gama Mahakam Samarinda, Samarinda.

Maulana, Erie. 2012. Panen Jamur Tiap Musim, Panduan Lengkap Bisnis dan Budidaya Jamur Tiram. Lily Publisher, Yogyakarta.

Muhyi, Abdul. 2016. Analisis Kultivasi Jamur Tiram Putih (Pleurotus ostreatus) Pada Log dan Ranting Kayu Karet Lamtoro, Randu dan Balsa. Skripsi (tidak dipublikasikan). Institut Pertanian Bogor. Bogor.

Piryadi, TU. 2013. Bisnis Jamur Tiram. Agromedia Pustaka, Jakarta. 
Rahmat, S., Nurhidayat. 2011. Untung Besar dari Bisnis Jamur Tiram. Agromedia Pustaka, Jakarta.

Rochman, Abdul. 2015. Perbedaan Proporsi Dedak Dalam Media Tanam Terhadap Pertumbuhan Jamur Tiram Putih (Pleurotus florida). Jurnal Agribisnis Fakultas Pertanian Unita Vol. 11 N0.13. April 2015.

Sastrosupadi, A. 2000. Rancangan Percobaan Praktis Bidang Pertanian. Kanisius, Yogyakarta.

Satriyanto, F. 2010. http://jamursekolahdolan.blogspot.com [online]. diakses tanggal 04 Maret 2016.

Setiagama, Rosa. 2014. Pertumbuhan dan Produktivitas Jamur Tiram Putih (Pleurotus ostreatus) Dengan Komposisi Media Tumbuh Serbuk Gergaji Kayu Sengon, Tandan Kelapa Sawit, Dan Ampas Tahu Yang Berbeda. [Naskah Publikasi]. Universitas Muhammadiyah Surakarta, Surakarta.

Simatupang, Erika., Murniati., Saputra, Sukemi Indra. 2013. Pengaruh Pemberian Beberapa Dosis Bekatul Pada Medium Serbuk Gergaji Terhadap Pertumbuhan Dan Produksi Jamur Tiram Putih (Pleurotus ostreatus). Universitas Riau, Riau.

Sugianto, Agus. 2017. Inovasi Teknologi TEL Jamur Tiram Putih untuk Melipatgandakan Produksi. Intimedia. Malang.

Suharnowo, Budipramana, Lukas S., Isnawati. 2012. Pertumbuhan Miselium dan Produksi Tubuh Buah Jamur Tiram Putih (Pleurotus ostreatus) dengan Memanfaatkan Kulit Ari Biji Kedelai sebagai Campuran pada Media
Tanam. Jurnal LenteraBio Vol. 1 No. 3 : 125130.

Sumarmi. 2006. Botani Dan Tinjauan Gizi Jamur Tiram Putih. INNOFARM : Jurnal Inovasi Pertanian Vol. 4, No. 2:124-130.

Sumiati, E., Suryaningsih, E., Puspitasari. 2006. Perbaikan Produksi Jamur Tiram Pleurotus ostreatus strain Florida dengan Modifikasi Bahan Baku Utama Substrat. J. Hort.16(2):96107.

Suriawiria, Unus. 2000. Sukses Beragrobisnis Jamur Kayu : Shiitake, Kuping dan Tiram. Penebar Swadaya. Jakarta.

Suriawiria, Unus. 2002. Budidaya Jamur Tiram. Kanisius, Yogyakarta.

Sutarman. 2012. Keragaan dan Produksi Jamur Tiram Putih (Pleurotus ostreatus) Pada Media Serbuk Gergaji Dan Ampas Tebu Bersuplemen Dedak dan Tepung Jagung. Jurnal Penelitian Pertanian Terapan. Vol.12(3): 163-168.

Widyastuti, N., Tjokrokusumo, D. 2008. Aspek Lingkungan Sebagai Faktor Penentu Keberhasilan Budidaya Jamur Tiram (Pleurotus Sp). J. Tek. Ling Vol. 9 No. 3 : 287293.

Wijoyo, PM. 2011. Cara Budidaya Jamur Tiram Yang Menguntungkan. Pustaka Agro Indonesia, Jakarta.

Winarni, Inggit., Rahayu, Ucu. 2002. Pengaruh Formulasi Media Tanam dengan Bahan Dasar Serbuk Gergaji Terhadap Produksi Jamur Tiram Putih (Pleurotus ostreatus). Laporan Penelitian. Pusat Studi Indonesia-Lembaga Pendidikan Universitas Terbuka. 